Jurnal Mahasiswa BK An-Nur : Berbeda, Bermakna, Mulia

Volume 7 Nomer 3 Tahun 2021

Tersedia Online: https://ojs.uniska-bjm.ac.id/index.php/AN-NUR

p-ISSN. 2460-9722 | e-ISSN. 2622-8297

\title{
APLIKASI LAPORAN KEGIATAN GURU BIMBINGAN DAN KONSELING BERBASIS WEB
}

\author{
Elok Maharany Mulkhis ${ }^{1}$, Aip Badrujaman ${ }^{2}$, Wirda Hanim ${ }^{3}$ \\ ${ }^{1}$ Fakultas Ilmu Pendidikan, Universitas Negeri Jakarta, Jakarta \\ Email: ${ }^{1}$ elokmaharani@yahoo.com, 2 aip_bj@yahoo.com, ${ }^{3}$ wirdahanim10@ gmail.com \\ Nomor HP : 081286444171
}

\begin{abstract}
ABSTRAK
Abstrak Penyusunan Laporan Bimbingan dan Konseling merupakan proses yang pendataan yang bersifat membuat deskripsi dan memberi uraian tentang analisis terhadap hasil yang telah dilakukan dalam kegiatan evaluasi sebelumnya. Kendala dalam penyusunan Laporan Bimbingan dan Konseling yang dihadapi guru BK diantaranya tidak adanya kelengkapan berkas laporan layanan yang sudah diberikan karena berkas hardcopy rentang hilang, dan mudah rusak, data catatan history siswa mengenai pelanggaran selama bersekolah tidak tercatat dengan baik, serta Data pribadi dan data pemeriksaan awal yang tidak lengkap. Tujuan penelitian ini adalah untuk mengetahui penerapan aplikasi laporan bimbingan dan konseling berbasis Web. Penelitian ini merupakan penelitian research and development. Penilaian hasil aplikasi laporan kegiatan bimbingan dan konseling berbasis website yang dilakukan oleh ahli materi, dengan nilai 80 mendapatkan kategori "Sangat Baik". Penilaian hasil aplikasi laporan kegiatan bimbingan dan konseling berbasis website yang dilakukan oleh ahli media, dengan nilai 62,5 mendapatkan kategori “Baik”.Penilaian hasil Uji Pengguna dapat dikatakan layak digunakan oleh guru BK. Hal ini terlihat dari aspek konsisten mendapat hasil 92\%, pada aspek kegunaan 97,5\%, pada aspek informatif mendapat 96,6\%, dan aspek mencegah kesalahan mendapat 96\%. Hal ini agar guru bimbingan dan konseling (BK) mempunyai arsip jika dibutuhkan dan mempermudah guru bimbingan dan konseling (BK) dalam memberikan layanan bimbingan konseling.
\end{abstract}

Kata Kunci: Aplikasi Laporan Bimbingan dan Konseling, Bimbingan dan Konseling, Siswa SMA

\begin{abstract}
The preparation of the Statements of Guidance and Counseling is the process of data collection that are making a description and give a description of the analysis of the results has been done in the evaluation of the activities previously. Constraints in the preparation of the Statements of Guidance and Counseling faced by teachers BK including the absence of the completeness of the file services report that has been given because the hardcopy range is gone, and easily damaged, the data record history students about violations during the school not recorded, as well as personal Data and inspection data, which is not complete. The purpose of this study was to determine the application of the report of the guidance and counseling Web-based. This research is research and development. Assessment of the results of the application report on the activities of guidance and counseling-based website that is carried out by material experts, with a value of 80 get the category of "Very Good". Assessment of the results of the application report on the activities of guidance and counseling-based website is made by media experts, with a value of 62.5 get the category of "Good". Assessment of the results of the User Test can be said to be used by teachers BK. It is seen from the aspect of consistently gets results $92 \%$, on the usability aspects of $97.5 \%$, on the aspect of information gets to $96.6 \%$, and the aspect of preventing mistakes got a 96\%. This is so the teachers guidance and counseling has archives if needed and easy teacher guidance and counseling in providing guidance and counselling.
\end{abstract}

Keywords: Guidance and Counseling Report Application, Guidance and Counseling, High School Students

Dipublikasikan Oleh :

UPT Publikasi dan Pengelolaan Jurnal

Universitas Islam Kalimantan Muhammad Arsyad Al-Banjari Banjarmasin 


\section{Elok Maharany Mulkhis ${ }^{1}$, Aip Badrujaman ${ }^{2}$, Wirda Hanim ${ }^{3}$}

Jurnal Mahasiswa BK An-Nur : Berbeda, Bermakna, Mulia

Volume 7 Nomer 3 Tahun 2021

Tersedia Online: https://ojs.uniska-bjm.ac.id/index.php/AN-NUR

p-ISSN. 2460-9722 | e-ISSN. 2622-8297

\section{PENDAHULUAN}

Pelaksanaan program Bimbingan dan Konseling harus ada pelaporan yang diberikan pada stakeholder. Layanan bimbingan dan konseling, selalu terdapat perencanaan, pelaksanaan, sampai dengan pelaporan yang merupakan hal ditunggu oleh stakeholder. Pelaporan merupakan proses yang dilakukan setelah tahapan evaluasi.Pelaporan yang segera, mudah diakses dan akuntabel mencerminkan kualitas/mutu layanan BK yang diselenggarakan, karena berdasarkan laporan dapat dilihat keberlanjutan dan keterkaitan antara satu jenis layanan dengan layanan lainnya Isi dalam pelaporan bersifat membuat deskripsi dan memberi uraian tentang analisis terhadap hasil yang telah dilakukan dalam kegiatan evaluasi sebelumnya.

Berdasarkan buku pedoman dari Kementrian Pendidikan dan Kebudayaan Republik Indonesia, Panduan Operasional Penyelenggaraan Bimbingan dan Konseling Sekolah Menengah Kejuruan "SMA", (2016:99) bahwa pelaporan pada hakikatnya merupakan kegiatan menyusun dan mendeskripsikan seluruh hasil yang telah dicapai dalam evaluasi proses maupun hasil dalam format laporan yang dapat memberikan informasi kepada seluruh pihak yang terlibat tentang keberhasilan dan kekurangan dari program bimbingan dan konseling yang telah dilakukan

Menurut Badrujaman (2011:17) mengungkapkan bahwa istilah akuntabilitas merujuk pada keadaan di mana pengelola progam mampu menjelaskan proses pelaksanaan, serta hasil yang dicapai dalam program yang menjadi tanggung jawabnya. Akuntabilitas merujuk pada tingkat kepercayaan stakeholder kepada program yang menjadi tujuan dilaksanakannya evaluasi. Berdasarkan Peraturan No. 111 tahun 2014 mengenai bimbingan dan konseling di tingkat pendidikan dasar dan pendidikan menengah. Oleh sebab itu, keberadaan Guru Bimbingan dan Konseling sebagai kualifikasi dan profesi pendidik yang memiliki keunikan konteks tugas dan ekspetasi kinerja.

Kemudian penelitian membuat dan menyebarkan kuesioner terbuka. Kuesioner terbuka ini terdiri dari 3 item pertanyaan dengan responden sebanyak 50 Guru BK SMA Kota Tangerang. Berdasarkan hasil rangkuman kuisoner terbuka dengan item pertanyaan nomor 1 mengenai bagaiamanakah keterlaksanaan kegiatan penyusunan laporan kegiatan disekolah, diperoleh data bahwa sebagian besar guru BK mengalami kurang optimal dalam pembuatan laporan dikarenakan kondisi sekolah sedang WFH saat masa pandemi Covid-19, dan format laporan kegiatan tidak sesuai POP BK. Dari hasil observasi didapatkan bahwa keterlaksanaan pembuatan laporan kegiatan bimbingan dan konseling mengalami kesulitan dikarenakan sekolah yang dilaksanakan secara WFH.

Berdasarkan hasil rangkuman hasil kuisoner terbuka dengan item pertanyaan nomor 2 mengenai hambatan dalam penyusun laporan kegiatan, diperoleh data bahwa sebagian besar guru BK mengalami hambatan pada pengerjaan dalam membuat laporan kegiatan dibutuhkan waktu yang lama, kurangnya informasi yang didapatkan mengenai suatu kasus karena pengerjaan laporan kegiatan masih manual, format laporan kegiatan yang sulit dipahami tidak sesuai dengan POP BK, dan kondisi tempat penyimpanan yang kurang baik sehingga membuat laporan yang telah dibuat tidak tersusun rapi, rusak bahkan hilang. Dari hasil observasi didapatkan bahwa hambatan dalam pembuatan laporan kegiatan berada pada tempat penyimpanan berkas laporan kegiatan yang memiliki kondisi kurang baik sehingga berkas laporan kegiatan tidak tertata dengan baik, rusak dan hilang. Kemudian proses pembuatan yang tidak efisien dimana masih melakukan pendataan secara manual. Hambatan-hambatan yang dialami dapat membuat guru BK tidak efektif dalam pembuatan laporan kegiatan.

Berdasarkan hasil rangkuman hasil kuisoner terbuka dengan item pertanyaan nomor 3 mengenai saran atau harapan anda sebagai Guru BK dalam memudahkan penyusunan laporan kegiatan, diperoleh data bahwa sebagian besar guru BK memberikan saran ataupun harapan untuk adanya aplikasi yang dapat memudahkan pembuatan laporan kegiatan bimbingan dan konseling, pihak yang terlibat bisa bekerja sama dengan baik, adanya format laporan kegiatan yang sederhana dan sesuai POP BK, disiplin dalam mengerjakan laporan kegiatan sehingga pendataan laporan bisa tersusun dengan baik dan rapi, memiliki tempat penyimpanan atau lemari untuk menyimpan arsip berkas laporan yang sudah dibuat sehingga berkas laporan kegiatan tersusun rapih, tidak rusak dan tidak hilang, memiliki ruang khusus untuk guru BK untuk mengoptimalkan layanan kepada siswa, komunikasi yang terbuka antara pihak yang terlibat. Dari hasil observasi didapatkan bahwa saran maupun harapan guru BK yakni adanya Aplikasi

Dipublikasikan Oleh :

UPT Publikasi dan Pengelolaan Jurnal

Universitas Islam Kalimantan Muhammad Arsyad Al-Banjari Banjarmasin 


\section{Elok Maharany Mulkhis ${ }^{1}$, Aip Badrujaman ${ }^{2}$, Wirda Hanim ${ }^{3}$ Jurnal Mahasiswa BK An-Nur : Berbeda, Bermakna, Mulia Volume 7 Nomer 3 Tahun 2021 \\ Tersedia Online: https://ojs.uniska-bjm.ac.id/index.php/AN-NUR p-ISSN. 2460-9722 | e-ISSN. 2622-8297}

khusus laporan kegiatan bimbingan dan konseling yang dapat memudahkan guru BK pembuatan laporan kegiatan dimana bisa menggunakan computer/laptop, smartphone serta memiliki format laporan kegiatan yang sederhana dan sesuai dengan POP BK. Dengan adanya aplikasi tersebut, besar harapan guru BK bisa bekerja lebih efisien dari segi tenaga, waktu, dan biaya serta bisa lebih efektif dari pencapaian tujuannya sehingga guru BK dapat membuat laporan kegiatan yang berkualitas.

Penelitian mengenai aplikasi berbasis data juga pernah diteliti oleh jurnal Riky Johan Pranata dan Saluman Rohman Nudin, S.Kom., M.Kom yang berjudul Rancang bangun aplikasi administrasi bimbingan konseling (AaBK) di SMK Kawung 2 Surabaya. Hasil dari penelitiannya dalam Aplikasi Administrasi Bimbingan Konseling (AaBK) terbukti membatu guru BK di SMK Kawung 2 Surabaya dalam melaksanakan tugasnya dalam mengelola administrasi bimbingan konseling. Dalam jurnal tersebut terdapat kekurangan, yakni penyusunan hanya meneliti terkait aplikasi berbasis data namun untuk pelaporan bimbingan dan konseling tidaklah lengkap.

Berdasarkan uraian di atas, maka dapat diketahui perlu adanya aplikasi berbasis web yang mampu mempermudah guru dalam menyusun laporan kegiatan bimbingan dan konseling. Maka dari itu penulis ingin mengkaji Aplikasi Laporan Kegiatan Guru Bimbingan dan Konseling Berbasis Web. Tujuan dibuatnya aplikasi ini untuk membantu para guru BK SMA kota Tangerang dalam penyusunan laporan kegiatan bimbingan dan konseling secara optimal.

Peneliti bertujuan untuk mengetahui penerapan ,efektifitas dan menghasilkan aplikasi laporan kegiatan guru bimbingan dan konseling berbasis web bagi guru BK di SMA Kota Tangerang.

\section{METODE}

Jenis penelitian yang di gunakan penelitian pengembangan atau Research and Development $(\mathrm{R} \&$ D). Penelitian pengembangan mencakup proses mencari, menemukan inovasi dan keunggulan dalam efektivitas penelitian, efisiensi dan produktivitas. Menurut Goll, Gall \& Borg, 2003 (Putra, 2012 : 84), menjelaskan $\mathrm{R} \& \mathrm{D}$ dalam pendidikan adalah sebuah model pengembangan berbasis industri dimana temuan penelitian digunakan untuk merancang produk dan prosedur baru, yang kemudian secara sistematis diuji di lapangan, dievaluasi dan disempurnakan sampai mereka memenuhi kriteria tertentu, yaitu efektivitas dan berkualitas.

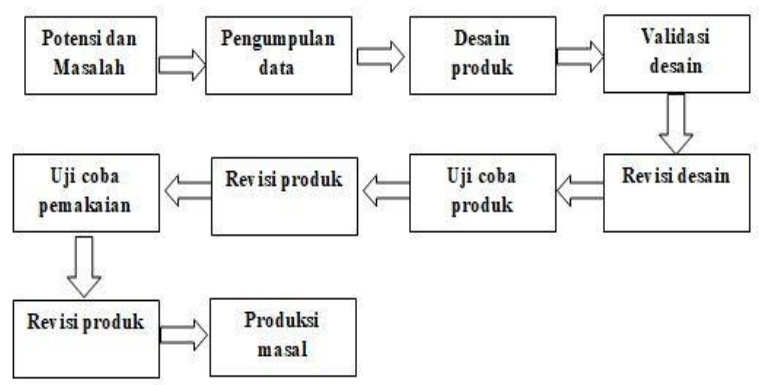

Gambar 1 Langkah-langkah penggunaan Metode Research and Development (R\&D)

Penelitian dilaksanakan di SMA Kota Tangerang yang terdiri dari SMA Negeri maupun SMA Swasta dengan waktu penelitian mulai bulan Juli 2020 sampai dengan Juni 2021. Subyek penelitian pada penelitian pengembangan ini terdiri dari 50 Guru BK dalam Analisa kebutuhan Guru, 1 ahli media, 1 ahli materi, dan 10 Guru BK pada Uji Pengguna.

Teknik pengumpulan data yang dilakukan oleh penliti dengan wawancara, kuesioner, dan observasi. Observasi dilakukan dengan melihat secara langsung tempat tersebut. Kuesioner dilakukan dengan cara memberikan beberapa pertanyaan kepada responden. Wawancara dilaksanakan dengan guru BK untuk memperoleh data mengenai kebutuhan dalam penelitian dan pengembangan.

Teknik analisis yang digunakan peneliti yakni analisis kualitatif dan analisis kuantitatif. Dalam analisis kualitatif, pengolahan data, anjuran dari uji ahli program BK dan guru BK sebagai pengguna program. Dalam analisis kuantitatitf, peneliti menggunakan skala likert .

\section{HASIL DAN PEMBAHASAN}

\section{a. Analisis Kebutuhan Guru BK}

Pengumpulan data awal melalui penyebaran kuesioner tertutup dan kuisoner terbuka dengan guru bimbingan konseling SMA Kota Tangerang sebagai responden. Penyebaran kuisoner secara online/daring menggunakan Google Form mengenai aplikasi laporan kegiatan berbasis web dengan responden Guru BK dimaksudkan untuk mengetahui proses pembuatan laporan, kebutuhan, kendala, pemanfaatan layanan BK dan harapan dari Guru BK dalam pembuatan laporan kegiatan BK. Kuisoner tertutup terdiri dari 41 item pernyataan dengan jumlah

Dipublikasikan Oleh :

UPT Publikasi dan Pengelolaan Jurnal

Universitas Islam Kalimantan Muhammad Arsyad Al-Banjari Banjarmasin 


\section{Elok Maharany Mulkhis ${ }^{1}$, Aip Badrujaman ${ }^{2}$, Wirda Hanim ${ }^{3}$ Jurnal Mahasiswa BK An-Nur : Berbeda, Bermakna, Mulia Volume 7 Nomer 3 Tahun 2021 \\ Tersedia Online: https://ojs.uniska-bjm.ac.id/index.php/AN-NUR p-ISSN. 2460-9722 | e-ISSN. 2622-8297}

responden 50 Guru BK SMA Kota Tangerang. Berdasarkan hasil kuisoner tertutup, diperoleh hasil sebagaimana disajikan pada Gambar sebagai berikut:

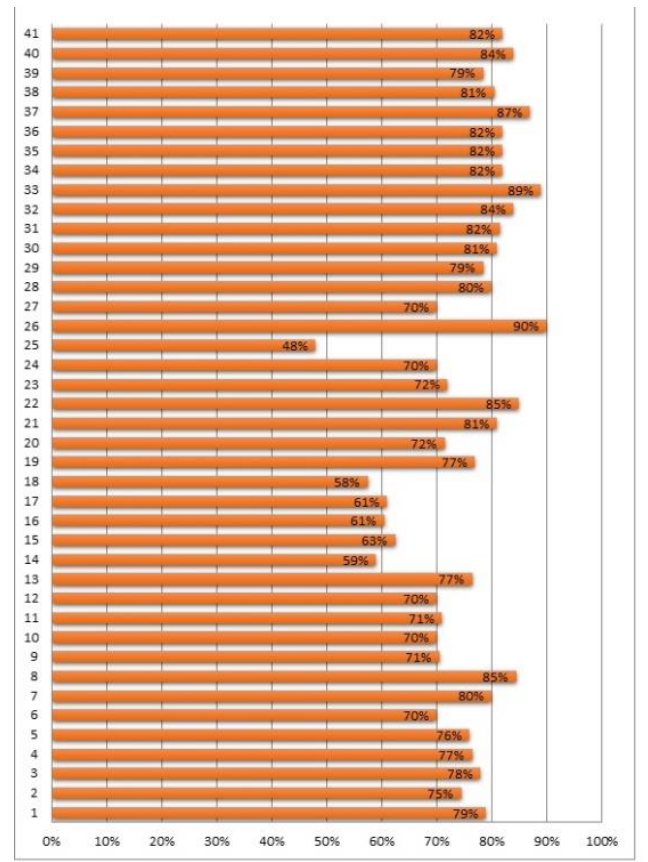

Sesuai dengan gambar di atas dengan pernyataan item nomor 1 sampai dengan item nomor 13 diperoleh informasi tentang laporan kegiatan secara terperinci, dimana responden membuat laporan konseling individual sebesar 79\%, laporan konseling kelompok $75 \%$, laporan bimbingan kelompok $78 \%$, laporan bimbingan klasikal $77 \%$, laporan bimbingan kelas besar $76 \%$, laporan konsultasi $70 \%$, laporan kolaborasi Guru 80\%, laporan kolaborasi orang tua $85 \%$, laporan kolaborasi ahli lain $71 \%$, laporan kolaborasi lembaga lain $70 \%$, laporan konferensi kasus $71 \%$, laporan kunjungan rumah $70 \%$, dan laporan kegiatan advokasi $77 \%$. Hal ini menunjukkan sebagian besar guru telah melakukan pembuatan laporan kegiatan dengan laporan kolaborasi orang tua yang paling besar presentase dimana laporan tersebut mendapatkan presentase sebesar $85 \%$.

Berdasarkan pemaparan tersebut, diharapkan Gambar Error! No text of specified style in - mbuatan document.2 Deskripsi Analisis Kebutuhan Guru untuk

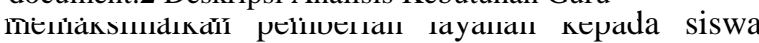
sehingga permasalahan siswa disekolah dapat terselesaikan serta memandirikan siswa.
Melihat gambar di atas dengan pernyataan item nomor 14 sampai dengan item nomor 25 diperoleh informasi tentang kendala dalam pembuatan laporan kegiatan, dimana fasilitas sekolah ketersediaan komputer menjadi penghambat dalam penyusunan laporan sebesar 59\%, ketersediaan internet menjadi penghambat dalam penyusunan laporan sebesar 63\%, ketersediaan lemari arsip menjadi penghambat dalam penyusunan laporan sebesar $61 \%$, keterbukaan siswa menjadi penghambat dalam penyusunan laporan sebesar $61 \%$, keterbukaan orang tua menjadi penghambat dalam penyusunan laporan sebesar 58\%, keterampilan guru menggunakan computer/laptop dalam pembuatan laporan sebesar $77 \%$, kondisi komputer diruang BK memiliki spesifikasi yang bagus sebesar $72 \%$, Guru BK dapat mengoperasikan komputer dengan baik sebesar $81 \%$, fasilitas internet diruang BK berjalan baik sebesar $85 \%$, proses administrasi laporan kegiatan disekolah berjalan baik sebesar $72 \%$, pencarian data siswa khususnya data kasus sekolah berjalan baik sebesar $70 \%$, dan kondisi tempat penyimpanan berkas kasus siswa disekolah memiliki kondisi yang bagus sebesar $48 \%$. Hal ini menunjukkan sebagian besar guru BK memiliki kendala untuk membuat laporan kegiatan dimana kondisi tempat penyimpanan berkas kasus siswa yang bagus adalah kendala paling disorot dimana kendala tersebut mendapatkan presentase sebesar $48 \%$.

Berdasarkan pemaparan ini, diharapkan Guru BK dan pihak sekolah dapat memfasilitasi dengan baik tempat penyimpanan berkas kasus dan laporan kegiatan siswa, hal ini untuk memudahkan guru BK dalam menyimpan, mencari dan merekap laporan kegiatan disetiap bulannya.

Dengan melihat gambar tersebut dengan pernyataan item nomor 26 sampai dengan item nomor 27 diperoleh informasi tentang kebutuhan aplikasi dalam pembuatan laporan kegiatan, dimana aplikasi berbasis web dapat memudahkan guru BK dalam membuat laporan sebesar 90\%, aplikasi berbasis local host (aplikasi tanpa menggunakan internet) dapat memudahkan guru BK dalam membuat laporan sebesar $70 \%$. Hal ini menunjukkan sebagian besar guru BK menginginkan aplikasi laporan kegiatan bimbingan dan konseling berbasis web dimana item tersebut mendapatkan presentase sebesar $90 \%$.

Berdasarkan pemaparan ini, diharapkan Guru BK memiliki Aplikasi laporan kegiatan layanan berbasis Web, hal ini bertujuan agar guru BK bisa bekerja lebih efisien dan efektif. Efisien yang

Dipublikasikan Oleh :

UPT Publikasi dan Pengelolaan Jurnal

Universitas Islam Kalimantan Muhammad Arsyad Al-Banjari Banjarmasin 


\section{Elok Maharany Mulkhis ${ }^{1}$, Aip Badrujaman ${ }^{2}$, Wirda Hanim ${ }^{3}$}

Jurnal Mahasiswa BK An-Nur : Berbeda, Bermakna, Mulia

Volume 7 Nomer 3 Tahun 2021

Tersedia Online: https://ojs.uniska-bjm.ac.id/index.php/AN-NUR

p-ISSN. 2460-9722 | e-ISSN. 2622-8297

dimaksud yakni guru BK dapat membuat laporan kegiatan dengan menghemat waktu, tenaga dan biaya sehingga membuat guru BK mampu melaksanakan pembuatan laporan kegiatan secara cermat dan tepat. Kemudian efektif yang dimaksud yakni guru BK berhasil membuat laporan kegiatan mencapai tujuan sesuai dengan program yang telah ditetapkan.

Berdasarkan Gambar dengan pernyataan item nomor 28 sampai dengan item nomor 41 diperoleh informasi tentang desain aplikasi layanan kebutuhan aplikasi dalam pembuatan laporan kegiatan, dimana jenis font (jenis huruf) dalam aplikasi laporan kegiatan dapat mempermudahkan guru BK dalam membuat laporan sebesar 80\%, penggunaan icon (symbol) dapat memudahkan guru BK dalam membuat laporan sebesar 79\%, ukuran font (ukuran tulisan) dalam aplikasi dapat memudahkan guru BK dalam membuat laporan sebesar $81 \%$, desain aplikasi yang baik dapat memudahkan guru BK dalam membuat laporan sebesar $82 \%$, dengan adanya fitur pencarian database kasus siswa dapat memudahkan guru BK dalam membuat laporan sebesar 84\%, harapan guru BK dengan aplikasi laporan kegiatan dapat print out data laporan berkala dari 1 hari hingga waktu yang sudah ditentukan sebesar $89 \%$, harapan guru BK dengan aplikasi laporan kegiatan yang memiliki grafik data laporan setiap jenis layanannya sebesar $82 \%$, aplikasi laporan kegiatan memiliki data diri siswa secara lengkap sebesar $82 \%$, aplikasi laporan kegiatan dapat melakukan pendataan sesuai jenis laporan kegiatan sebesar $82 \%$, aplikasi laporan kegiatan dapat melakukan pencarian data berdasarkan nama siswa sebesar $87 \%$, aplikasi laporan kegiatan dapat melakukan pencarian data berdasarkan jenis layanan sebesar $81 \%$, aplikasi laporan kegiatan dapat melakukan print out rekapitulasi berdasarkan jenis layanan sebesar 79\%, aplikasi laporan kegiatan memiliki kemudahan dalam penyusunan jenis layanan sebesar $84 \%$, dan aplikasi laporan kegiatan memiliki Form sesuai jenis layanan sebesar $82 \%$.

Hal ini menunjukkan sebagian besar guru BK menginginkan aplikasi laporan memiliki fitur untuk print out laporan berkala dari 1 hari hingga waktu ditentukan merupakan item dengan presentase terbesar dimana item tersebut mendapat presentase sebesar $89 \%$. Berdasarkan pemaparan ini, diharapkan Guru BK memiliki Aplikasi laporan kegiatan yang dapat print out laporan secara berkala dari 1 hari hingga waktu yang sudah ditentukan, hal ini bertujuan ketika stakeholder meminta rekapitulasi hasil laporan kegiatan yang sudah diberikan guru BK kepada siswa berdasarkan periode waktunya.

\section{b. Uji Ahli Materi}

Penilaian uji ahli materi mendapatkan nilai 80 dan mendapatkan kategori Sangat Baik

\section{c. Uji Ahli Media}

Penilaian uji ahli media mendapatkan nilai 62,5 dan mendapatkan kategori Baik

\section{d. Uji Pengguna}

Dari hasil uji pengguna dapat diaktakan layak digunakan oleh guru BK

\section{PENUTUP}

Kesimpulan yang dapat diambil berdasarkan hasil penelitian ini, yaitu:

1. Hasil penelitian ini dapat menghasilkan produk berupa aplikasi laporan kegiatan bimbingan dan konseling yang dapat digunakan oleh Guru BK. Aplikasi laporan kegiatan yang dibuat terdiri dari 13 informasi mengenai laporan kegiatan yaitu (1) layanan konseling individu, (2) konseling kelompok, (3) bimbingan kelompok, (4) bimbingan klasikal, (5) bimbingan kelas besar, (6) konsultasi, (7) kolaborasi guru, (8) kolaborasi orang tua, (9) kolaborasi ahli lain, (10) kolaborasi lembaga lain, (11) konferensi kasus, (12) kunjungan rumah dan (13) layanan advokasi.

2. Penilaian hasil aplikasi laporan kegiatan bimbingan dan konseling berbasis website yang dilakukan oleh ahli materi, dengan nilai 80 mendapatkan kategori "Sangat Baik"

3. Penilaian hasil aplikasi laporan kegiatan bimbingan dan konseling berbasis website yang dilakukan oleh ahli media, dengan nilai 62,5 mendapatkan kategori "Baik"

4. Penilaian hasil Uji Pengguna dapat dikatakan layak digunakan oleh guru BK. Hal ini terlihat dari aspek konsisten mendapat hasil 92\%, pada aspek kegunaan 97,5\%, pada aspek informatif mendapat $96,6 \%$, dan aspek mencegah kesalahan mendapat $96 \%$.

5. Terdapat kelemahan dalam aplikasi yang dikembangkan yaitu fungsi fitur pada aplikasi tidak berjalan secara optimal. Hal ini dikarenakan komunikasi antara peneliti dengan Tim IT.

Dipublikasikan Oleh : 
Elok Maharany Mulkhis ${ }^{1}$, Aip Badrujaman ${ }^{2}$, Wirda Hanim ${ }^{3}$

Jurnal Mahasiswa BK An-Nur : Berbeda, Bermakna, Mulia

Volume 7 Nomer 3 Tahun 2021

Tersedia Online: https://ojs.uniska-bjm.ac.id/index.php/AN-NUR

p-ISSN. 2460-9722 | e-ISSN. 2622-8297

Hasil penelitian ini terdapat beberapa kekurangan. Oleh karena itu, peneliti memberikan saran sebagai berikut:

1. Bagi guru BK

a. Guru BK dapat menggunakan produk aplikasi Laporan Guru Bimbingan dan Konseling Berbasis Web sehingga memudahkannya dalam menyusun laporan layanan BK pada peserta didik tanpa terganggu batasan ruang dan waktu.

b. Sebaiknya, dilakukan penyebarluasan lebih lanjut agar aplikasi Laporan Guru Bimbingan dan Konseling Berbasis Web dapat diakses lebih luas melalui forum MGBK (Musyawarah guru bimbingan konseling) pada setiap kota.

2. Bagi Sekolah

Memanfaatkan kebijakan dalam menggunakan aplikasi Laporan Guru Bimbingan dan Konseling Berbasis Web agar mengoptimalkan layanan BK

3. Bagi peneliti selanjutnya

Keterbatasan pada penelitian yang dilakukan yaitu keterbatasan waktu dalam pembuatan aplikasi, sehingga aplikasi tidak secara optimal dapat berkembang. Peneliti sudah berganti tim IT sebanyak dua kali dikarenakan sulitnya peneliti mendapatkan tim IT yang dapat membuat produk sesuai rancangan peneliti. Sehingga peneliti menyarankan untuk peneliti berikutnya yaitu melihat kemampuan SDM dalam bidang IT, sehingga produk dapat dibuat berdasarkan rancangan yang telah dibuat peneliti

\section{REFERENSI}

Badrujaman, A. 2011. Teori dan Aplikasi Evaluasi Program Bimbingan dan Konseling. Jakarta: Indeks

Johan Pranata, R. (2018) 'Rancang Bangun Aplikasi Administrasi Bimbingan Konseling (Aabk) Di Smk Kawung 2 Surabaya'. Jurnal Teknik Informatika.

Kementerian Pendidikan Dan Kebudayaan Direktorat Jenderal Guru Dan Tenaga Kependidikan. 2016. Panduan Operasional Penyelenggaraan Bimbingan Dan Konseling Sekolah Menengah Atas (SMA). Jakarta
Peraturan Menteri Pendidikan dan Kebudayaan Republik Indonesia. No. 111 Tahun 2014. Bimbingan dan Konseling pada Pendidikan Dasar dan Pendidikan Menengah.

Putra, Nusa. 2012. Research \& Development Penelitian dan Pengembangan : Suatu Pengantar. Jakarta : Raja Grafindo Persada.

Dipublikasikan Oleh :

UPT Publikasi dan Pengelolaan Jurnal

Universitas Islam Kalimantan Muhammad Arsyad Al-Banjari Banjarmasin 